\title{
GREEN SUPPLY CHAIN MANAGEMENT - Food for Thought?
}

\author{
Name: $\quad$ Abdul Ali, Yongmei Bentley, Guangming Cao
}

University of Bedfordshire Business School, University of Bedfordshire, UK

Name: Dr. Farooq Habib

Institution: Cranfield School of Management, Cranfield University, UK

\begin{abstract}
This paper investigates the impact of green supply chain management (GSCM) practices on the performance of UK food retail small and medium-sized enterprises (SMEs). A quantitative approach using a nonprobability sampling of 84 participants was employed. Based on the literature review, five hypotheses were developed and tested using the partial least square-structural equation modelling (SEM-Smart PLS 2.03) approach. The reviewed literature revealed that key internal drivers (ID) and external pressures (EP) stimulate organizations to initiate GSCM Practices in UK food retail SMEs. Though empirical findings strongly supported the statement that ID influence GSCM practices but they did not show a significant relationship between EP and GSCM practices. Literature also suggests that practicing GSCM can help improve the efficiency, brand image (BI) and profitability, and thus improve the overall firm performance which is also empirically proved. This study helps enrich existing theories on SCM and organizational performance. As to practical impact, this study should facilitate SMEs in GSCM practices and thus help green the economy. While the findings of this study have limited generalizability as the data were collected from UK SMEs only and the sample size was comparatively small, this research establishes a foundation for further study in this domain.
\end{abstract}

Key Words: Green supply chain management, food retail, small and medium-sized enterprise, Performance, Sustainable Supply Chain, UK 


\section{Introduction}

Sustainable or green Supply Chain Management (SCM) has been an ever increasingly researched area for decades (Sarkis, 2012; Touboulic and Walker, 2015) and a key challenge for companies and supply networks (Vachon and Klassen, 2006; Azevedo et al., 2011; Kuei et al., 2015). Green Supply Chain Management (GSCM), which incorporates environmental thinking into SCM activities, has gained popularity in the academia (Laosirihongthong et al., 2013; Zhu et al., 2013) due to environmental degradation, increased $\mathrm{CO}_{2}$ emissions and climate change threatening human existence and natural inhabitants (Hoskin, 2011). Lee (2015) mentioned that these challenges come from global environmental regulations, green consumerism and climate change. Organisations are now compelled to rethink managerial behaviour towards green practices including implementation of environmental audits, maintaining certifications such as ISO 14001 and collaboration with stakeholders (Vachon and Klassen, 2008). However, organisations will prefer the options which make sense for businesses (Bowen et al., 2001).

Much of the debate on GSCM is to determine the drivers, motivations, or pressures in undertaking GSCM initiatives (Diabat and Govindan, 2011; Govindan et al., 2014) and its influences on organisational performances (Green Jr et al., 2012; Lee et al., 2012; Zhu et al., 2012; Laosirihongthong et al., 2013; Lee, 2015). There is also a growing research in the role of supply chain (SC) collaboration on sustainability (Vachon and Klassen, 2008; Ramanathan et al., 2014; Grekova et al., 2015; Gunasekaran et al., 2015). However, there have been limited studies on SCM practices of Small and Medium-Sized Enterprises (SMEs) (Quayle, 2003; Saad et al., 2006; Lenny Koh et al., 2007; Vaaland and Heide, 2007; Thakkar et al., 2009) and only a few studies on GSCM practices of SMEs (Aragon-Correa et al., 2008; Lee, 2008; Huang et al., 2012; Lee et al., 2012; Bourlakis et al., 2014; Huang et al., 2015), and no research has been found on UK food retail SMEs that has a particular focus on GSCM. This reflects a substantial gap in the literature. This research attempts to fill the gap by identifying existing GSCM practices and their impacts on the performance of UK Food retail SMEs.

Integrating environmental thinking into SCM is becoming a strategic issue for businesses in order to satisfy all stakeholders across the SC. It has also become fundamental for businesses to implement GSCM practices in order to generate competitive advantages and cope with increasing number of environmental regulations at various levels (regional, national, international)(Green Jr et al., 2012). However, developing and implementing environmentally friendly practices and processes require certain kind of motivation or drivers. Drivers may come from within the organisation or from outside organisation, for instance, government, environmental agencies, market forces and customer expectations. In this study, this will be highlighted from the perspective of institutional theory. The 
implementation of GSCM practices is expected to improve the business performance of organisations, and boost brand image which will ultimately enhance profitability. Green Jr et al. (2012) claimed that whether GSCM pays has been inconclusively investigated in the previous researches (Zhu and Sarkis, 2004; Rao and Holt, 2005). Therefore, there is a dearth of research in this area that could be used as a base for either theory building or theory testing(Green Jr et al., 2012).

Examining how GSCM is practiced by UK food retail SMEs and how that impacts on the performance outcome is essential because in the UK approximately $99 \%$ businesses fall under SMEs (Walker and Preuss, 2008; Ward and Rhodes, 2014). In addition, the recent horse meat scandal in the UK (Touboulic and Walker, 2015) has triggered a massive corporate storm throughout the SC of every company, food supply networks in particular, to make SCs more transparent and more visible in order to achieve consumers' confidence and to avoid reputational damage (Carter and Rogers, 2008). Food SCs, in one way or another, significantly depend on SMEs. If these SMEs can be motivated to take purposeful action in greening $\mathrm{SCs}$, it is likely that the problems such as $\mathrm{CO}_{2}$ emissions from food SCs will significantly be reduced. However, proper attention has not yet been given in researching GSCM practices in SMEs and even less to the impact on firm performance. The endeavour of this study is to fill this gap and contribute to the body of knowledge in SMEs' GSCM and its impact on performance. This study focuses on the following three objectives:

(a) To identify the motivating factors for SMEs in undertaking GSCM initiatives;

(b) To ascertain the existing GSCM practices in UK food retail SMEs; and

(c) To empirically test the impacts of GSCM practices on organisation performance.

In order to fulfil the research objectives, based on the reviewed literature, a survey questionnaire was developed to collect data to test the proposed hypothesis for this study. It is hoped that this study can help SMEs better understand GSCM practices, the driving forces and potential performance outcome. All this should stimulate SMEs to join the green movement. Hopefully, this will accelerate the process of greening the economy and build a better planet for the future generation.

The remaining paper is organised as follows: Section 2 highlights the review of previous research on GSCM and performances; Section 3 presents the hypotheses and the conceptual model from this research; Section 4 discusses the research methodology adopted for this study; Section 5 outlines the data analysis and discussion of the key findings; section 6 highlights theoretical and managerial implications of this study; and finally, Section 7 presents summary and conclusion together with research contributions, limitations and opportunities for further research. 


\section{Literature review}

This section presents a review of literature, including GSCM, drivers and pressures for adopting GSCM practices, GSCM practices for SMEs, and GSCM and its performance implications. Based on the literature, five hypotheses were developed, and a conceptual framework on the impact of GSCM practices on the performance of UK food retail SMEs was proposed.

\subsection{Green Supply Chain Management}

Green Supply Chain Management (GSCM) which takes environmental issues into consideration is the extension of traditional SCM. Slack et al. (2009) defined Supply Chain (SC) as the linked operations to source and provide goods and services to the end users. GSCM follows similar activities but in a way that is more innovative, profitable, widely acceptable, socially and environmentally responsible (Sarkis et al., 2011; Zhu et al., 2012).

The reviewed literature indicates that scholars have used different terminologies to comprehend GSCM over the period of time, for instance, cleaner SCM (Subramanian and Gunasekaran, 2015), Sustainable Supply Chain Management (SSCM) (Linton et al., 2007; Seuring and Müller, 2008; Gold et al., 2010; Ahi and Searcy, 2013; Beske et al., 2014; Touboulic and Walker, 2015), environmental SC (Jabbour et al., 2015), green practices of SC (Azevedo et al., 2011), and socially responsible SC (Hoejmose et al., 2013). Many scholars have tried to define GSCM from various perspectives. For example Tachizawa et al. (2015) classified monitoring based and collaboration based GSCM practices, Testa and Iraldo (2010) from three different strategic perspectives illustrated GSCM as reputation related, efficiency related and innovation related while Azevedo et al. (2011) recommended GSCM practices as greening the supply process, product based practices, delivery process and green practices through cooperating with suppliers and customers. Though the views are not identical, but the notions are similar. Evaluation of GSCM is historical. Its dimensions, definitions and level of acceptance have changed significantly since it first emerged in the practical and academic domain. There are some subtle and few obvious differences among the terminologies used to denote GSCM or SSCM including the definitions, scopes and characteristics of the practices. Ahi and Searcy (2013) have made an attempt to distinguish the definitions between GSCM and SSCM claiming that SSCM is the extension of GSCM. There is considerable overlap among the definitions. However, Ahi and Searcy (2013) could not identify any complete definition for either GSCM or SSCM but the debate is still on. In this study, GSCM is defined as the combination of environmental, societal and economic consideration in a supply chain which operates as linked activities starting from sourcing raw materials to post consumption activities of products or services by the customers. However, the motivating factors for adopting GSCM practices in UK SME sector are yet to be proved. 
In this paper, an attempt is made to discuss those factors in the context of UK food retail SMEs by focusing on environmental aspect of the SC, and the impact of such GSCM on business performance.

\subsection{Drivers and Pressures for GSCM}

Organisations practice GSCM proactively or reactively (Laosirihongthong et al., 2013). Those driving forces can be from within the organisation (internal) or from outside the organisation (external). Many researchers (Testa and Iraldo, 2010; Zailani et al., 2012; Lee et al., 2013) maintain the view that internal drivers and external pressures induce organisations to practice GSCM. However, Laosirihongthong et al. (2013) mentioned reactive pressures and proactive drivers instead of internal drivers and external pressures that drive firms practicing GSCM. Tachizawa et al. (2015) distinguished coercive (regulations and environmental standards) and non-coercive drivers for GSCM practices.

Some of the organisational theories such as resources based view, resource dependence theory, and institutional theory have been used to understand how firms succeed in implementing certain operations strategies (Sarkis et al., 2011; Lee et al., 2012; Laosirihongthong et al., 2013; Lee et al., 2013). Diverse entities in GSCM act to fulfil business needs, customer expectations and legitimate requirements. Businesses receive pressures from regulatory bodies and increased influence from customers for a cleaner, transparent, socially and environmentally responsible supply chain (Zailani et al., 2012). Due to these pressures from outside and driving forces from within the organisation such as organisational values, corporate commitment and long term vision, companies are institutionalising environmental practices in business operations. In this sense, institutional theory is suitable for understanding the phenomena. Moreover, several studies(Zhu and Sarkis, 2007; Sarkis et al., 2011) have identified institutional theory as a key source in identifying influencing factors to practice GSCM. Hence, this study is guided by the institutional theory to understand the motivating factors of GSCM practices. Based on institutional theory (Dimaggio and Powell, 1983), Sarkis et al. (2011) highlighted three isomorphic drivers of GSCM namely Coercive pressures - governments, environmental interest groups, and industrial associations; Normative pressures - social pressures, consumer expectation, communities and wider stakeholders (Seuring and Müller, 2008); and Mimetic - coping the activities of a successful organisation i.e. competitive benchmarking. The higher the coercive pressure is, the higher the tendency of the firm to practice GSCM (Zhu and Sarkis, 2007; Testa and Iraldo, 2010). For instance, in order to avoid legislative hassles and to comply with current rules and regulations, firms accept certain level of green practices in business operations including reduced $\mathrm{CO}_{2}$ emission, design eco-friendly products, and try to avoid environmentally hazardous substances during the procurement and production process. 
Nonetheless, Testa and Iraldo (2010) argued that the pressures can be from inside the organisation for instance strategic motivation (Laosirihongthong et al., 2013). In contrast, normative drivers are the social reaction towards GSCM whereas the companies who follow market leaders to survive in the market face mimetic pressures. In contrast, internal drivers are company's commitment from the top executives (Zhu and Sarkis, 2004; Laosirihongthong et al., 2013) in line with organisational values (Testa and Iraldo, 2010), support from mid-level managers as well as senior employees (Zhu and Sarkis, 2007) and long term vision for expected business gains. Tachizawa et al. (2015) who classified GSCM practices as monitoring and collaboration based and revealed that non-coercive drivers have positive impact on both of the GSCM approaches (monitoring and collaboration) while coercive drivers suggested different implications as having positive impact on monitoring based GSCM practices but negative impact on collaboration based GSCM practices. Moreover, organisational aspiration to achieve cost leadership (cost minimization) and differentiation (innovation) strategy as well as to secure confidence, trust and respect from stakeholders all contribute to shaping SCM strategies. To understand the pressures and the drivers of GSCM, a number of studies have been conducted (see Table 1).

Table 1 Summary of key drivers and pressures from earlier empirical studies

\begin{tabular}{|l|l|l|}
\hline \multicolumn{1}{|c|}{ Aims and issues and sectors } & Sources of Drivers/Pressures & \multicolumn{1}{|c|}{ Source } \\
\hline $\begin{array}{l}\text { Exploring the GSCM pressures/drivers } \\
\text { (motivators), initiatives and performance of the } \\
\text { automotive SC using an empirical analysis of } 89 \\
\text { automotive enterprises within China }\end{array}$ & $\begin{array}{l}\text { Regulative } \\
\text { Market forces } \\
\text { Suppliers } \\
\text { Internal }\end{array}$ & Zhu et al., (2007) \\
\hline $\begin{array}{l}\text { Exploring the factors that drive or hinder } \\
\text { organisations to implement GSCM initiatives in } \\
\text { public and private sectors }\end{array}$ & $\begin{array}{l}\text { Organisation's internal factors } \\
\text { Legislative and regulatory } \\
\text { Customer's expectation } \\
\text { Market forces } \\
\text { Societal factors } \\
\text { Suppliers }\end{array}$ & $\begin{array}{l}\text { Walker } \text { et al. } \\
\text { (2008) }\end{array}$ \\
\hline $\begin{array}{l}\text { Examining environmental sustainability through } \\
\text { the management of SCs, focusing on a sample } \\
\text { of UK manufacturers }\end{array}$ & $\begin{array}{l}\text { Regulations } \\
\text { Societal drivers } \\
\text { Customer's pressures } \\
\text { Internal drivers }\end{array}$ & $\begin{array}{l}\text { Holt and } \\
\text { Ghobadian } \\
\text { (2009) }\end{array}$ \\
\hline $\begin{array}{l}\text { Exploring the driving forces behind SMEs' green } \\
\text { investment in SC and to provide an integrated } \\
\text { model of adopting green SC practices. }\end{array}$ & $\begin{array}{l}\text { Firm's Commitment and } \\
\text { managerial role } \\
\text { Experiences and } \\
\text { organisational cultures } \\
\text { External pressures }\end{array}$ & $\begin{array}{l}\text { Chen and Lee } \\
\text { (2010) }\end{array}$ \\
\hline $\begin{array}{l}\text { Identifying the drivers in implementing GSCM } \\
\text { practices through Interpretive Structural } \\
\text { Modelling (ISM) approach. }\end{array}$ & $\begin{array}{l}\text { Regulations } \\
\text { Customer Requirements } \\
\text { Expected Business Gains }\end{array}$ & $\begin{array}{l}\text { Diabat and } \\
\text { Govindan (2011) }\end{array}$ \\
\hline
\end{tabular}




\begin{tabular}{|l|l|l|}
\hline $\begin{array}{l}\text { Exploring GSCM practices and relationship with } \\
\text { organizational performance of SMEs that serve } \\
\text { as suppliers to large customer firms in the } \\
\text { electronics industry in Korea. }\end{array}$ & $\begin{array}{l}\text { Regulations } \\
\text { Corporate goal and product } \\
\text { positioning } \\
\text { Company image }\end{array}$ & Lee et al. (2012) \\
\hline Impact of GSCM practices and its performances & $\begin{array}{l}\text { Customer's requirements } \\
\text { Regulations } \\
\text { Internal Practices }\end{array}$ & $\begin{array}{l}\text { Green Jr } \text { et al. } \\
\text { (2012) }\end{array}$ \\
\hline $\begin{array}{l}\text { Identifying the pressures that effect GSCM } \\
\text { performance in South Korean Manufacturing } \\
\text { firms }\end{array}$ & $\begin{array}{l}\text { Internal Drivers } \\
\text { External Pressures }\end{array}$ & Lee et al. (2013) \\
\hline $\begin{array}{l}\text { Examining the deployment of pro-active and re- } \\
\text { active practices in the implementation of GSCM } \\
\text { and analyse the impact on environmental, } \\
\text { economic, and intangible performance by } \\
\text { considering business strategy as organizational } \\
\text { focus }\end{array}$ & $\begin{array}{l}\text { Pro-active practice - green } \\
\text { purchasing practices, eco- } \\
\text { design practices, reverse } \\
\text { logistics practices; } \\
\text { Re-active practice - } \\
\text { legislation and regulation }\end{array}$ & $\begin{array}{l}\text { Laosirihongthong } \\
\text { et al. (2013) }\end{array}$ \\
\hline $\begin{array}{l}\text { Analysing interrelationships among } \\
\text { environmental drivers, GSCM practices and } \\
\text { performance }\end{array}$ & $\begin{array}{l}\text { Coercive } \\
\text { Non-Coercive }\end{array}$ & $\begin{array}{l}\text { Tachizawa et al. } \\
\text { (2015) }\end{array}$ \\
\hline $\begin{array}{l}\text { Identifying the critical factors that influence in } \\
\text { GSCM adoption and the associated } \\
\text { performances. }\end{array}$ & $\begin{array}{l}\text { Technological } \\
\text { Internal Organisational } \\
\text { External Environmental }\end{array}$ & Kuei et al. (2015) \\
\hline
\end{tabular}

As Table 1 indicates, the drives and pressures come from various Sources. However, scholars such as Laosirihongthong et al. (2013;) and Testa and Iraldo, (2010) suggested that practicing GSCM should make sense from business point of view as businesses need to consider other performance objectives in the operations such as cost, quality, flexibility and reliability. Nonetheless, Carter and Rogers (2008) highlighted that to be sustainable a firm has to have core beliefs, cultures and a sense of purpose beyond the economic benefits. So it is evident that GSCM is not only an operational response for external stimuli but also an internal strategic vision aiming to achieve better environmental, operational and economic results.

\subsection{GSCM practices in SMEs}

Although large multinational enterprises (MNEs) are quickly moving towards greening the SCs and some have started to have positive social, environmental and economic impacts, SMEs, due to limited resources, lack of interest, or understanding of long term rewards, are lagging behind significantly. Consequently, SMEs are losing competitive advantage for not practicing GSCM (Seuring and Müller, 2008). , In order to achieve competitive advantage, GSCM practices are becoming unavoidable reality for SMEs (Huang et al., 2012). However, it is argued that SMEs are having difficulties in practicing GSCM as SMEs are in short of knowledge, technologies, expertise, financial and human resources (Huang et al., 2012; Lee et al., 2012). It is also an argumentative topic in 
literature as to whether GSCM fits with SMEs. Vaaland and Heide (2007) stated that in spite of having substantial benefits of SCM, SMEs are not fully capable of harnessing the advantage of SCM and face difficulties when implementing SCM initiatives especially those for GSCM.SMEs in the UK are diverse and heterogeneous in nature (Hillary, 2004) which may be the hindrance to practice GSCMGSCM in a structured way. However, in order to achieve competitive edge, gain consumer attention, and keep sustainable growth, SMEs need to be brought on-board and seek new opportunities and innovation in GSCM. GSCM practices can provide good innovative opportunities for SMEs to enhance production, reduce costs and minimise environmental damage (Zhu et al., 2007).

Some SMEs that follow ISO 14001 have started to develop initiatives such as green design, green production, green distribution, and reverse logistics as the GSCM practices (Chen and Lee, 2010), and there are a few studies on SMEs' GSCM practices. Laosirihongthong et al. (2013) proposed proactive and reactive environmental practices but implied that SMEs do not have adequate proactive environmental strategies, green awareness and environmental controlling systems. Zhu et al., (2007) proposed a set of practices in the study on GSCM, including internal environmental management, green purchasing, investment recovery, cooperation with customers and eco-design. Aspects of the GSCM practices considered in this study are explained below:

Internal Environmental Management (IEM): IEM is the practice of developing GSCM as a strategic imperative through commitment and support of senior mid-level managers (Zhu et al., 2007). Many researchers (i.e., Bowen et al. (2001); Lee et al. (2012); Tseng et al. (2014))support this view, saying that it is essential to have support from top management in order to make commitment and encouragement to achieve corporate environmental objectives. In SMEs, generally the owner or the manager is directly involved in the operations. So, the commitment and support are important.

Green Purchasing (GP): GP has drawn significant attention among enterprises. It is important to procure products from the firms that are also implementing GSCM practices. Moreover, supplier selection is crucial and a key strategic route for firms to reduce environmental impact on operations (Tseng and Chiu, 2013). Tseng et al. (2014) highlighted that green activities for a firm need to include strategic green purchasing. A recent study by Banaeian et al. (2015) formulated an integrated framework which has green supplier selection criteria for food SCs. These criteria can guide decision makers in the selection of suppliers. For example, firms with an ISO14001 certification can be more possibly selected as suppliers for larger food retailers such as TESCO, Sainsbury's or Morrison. 
Investment Recovery (IR): Zhu et al., (2007) described investment recovery as the sale of excess inventories, scrap and used materials, and excess capital equipment. Investment recovery can be seen as the utilisation of idle resources for better purposes (Jabbour et al., 2015), closed loop of reuse and recycle of by-products. In this way an organisation can reuse or remanufacture products economically while reducing its negative impact on environment.

Cooperation with Customers (CC): Tseng et al. (2015) argued that firms are unlikely to perform well if GSCM is practiced in isolation. To mitigate ever increasing environmental concerns of various stakeholders, a firm should pay attention to external partners of the SC along with internal business operations (Laari et al., 2016). Downstream buyers or customers are essential to help reduce environmental impact of the organisation and cooperation with customers significantly determines SMEs profit. Because food retail SMEs are directly engaged with customers, SMEs can encourage customers to reuse, and recycle to reduce waste. Cooperating with customers helps customers understand a company's intention of GSCM practices and the company can also better understand customer expectation and requirements. In addition, this can help improve customer satisfaction, because of having close contact with customers and local organisations, SMEs have greater opportunities in understanding, encouraging and collaborating with customers for environmental practices. The GSCM practices proposed by Zhu et al. (2007) were implemented in Chinese SMEs by (Huang et al., 2012; Huang et al., 2015). These practices have won some recognition and were adopted by some later studies including Lee et al.(2012), and Laosirihongthong et al. (2013). This study investigated the drivers and pressures of GSCM practices on UK food retail SMEs and the impact of GSCM practices on their performance.

\subsection{GSCM and Performance}

The relationship between practicing GSCM and organisational performance is a controversial topic. Some scholars (Bowen et al., 2001; Zhu et al., 2005; Eltayeb et al., 2011; Green Jr et al., 2012; Zailani et al., 2012) found that GSCM practices improve environmental, operational, economic and overall organisational performance, but Lee et al. (2013) claimed that there is an indirect relationship. Rao and Holt (2005) stated that GSCM practices enhance efficiency and bring synergy among strategic business units which minimize waste, save costs and improves environmental efficiency. In the view of Tseng et al. (2015), the association between GSCM practices and business performance has been comprehensively researched and it is argued that firms will not perform well if the capabilities are applied in isolation. In order to balance triple bottom line performance, organisations are aggressively integrating green practices within the business operations (Wu et al., 2015). 
Organisational performance has been measured by different academics using dissimilar components. For instance Zhu et al. (2005) investigated GSCM pressures, practices and performance in Chinese firms; De Giovanni and Esposito Vinzi (2012) examined environmental management and performance; Green Jr et al. (2012) explored GSCM practices and firm performance proving positive association using components as environmental, operational and economic performance; Wittstruck and Teuteberg (2012) measured three dimensions of performance - environmental, economic and social; Testa and Iraldo (2010) had an additional dimension on performance - brand image which was also used by Eltayeb et al. (2011) as intangible outcomes; Zailani et al. (2012) measured social performance of an organisation by means of product image, company image and stakeholders perceptions. Practicing environmentally friendly procedures help improve brand image (Zhu and Sarkis, 2004; Slack et al., 2009) but Zailani et al. (2012) mentioned that for SMEs brand image is not that significant.

Large businesses often find GSCM profitable because reducing waste including reduction of increasing buffer stocks; illuminating obsolescence cost, warehousing costs, energy reduction and minimizing defects directly impact on profitability. Simultaneously, following the 5 R's (recycling, reusing, redesigning, refurbishing and reverse logistics) indirectly influences profitability by reducing production costs. Besides, practicing GSCM improves corporate image which brings positive consumer behaviour about the corporations resulting added turnover and profitability (Zhu et al., 2007; Lee et al. (2012). Practicing GSCM can positively influence efficiency in working process, lead time and service quality of the organisation. GSCM practices send positive messages to the stakeholders about the company and its activities. This helps the firm in attracting consumers and media's attention which in turn change consumer perception and buying behaviour.

However, as a firm's supply chain becomes global, its challenge increases for the firm to maintain manufacturing and distributing units, distance and cultural diversity which increase risk such as inventory control, product quality, lead time and mutual trust. For this reasons, many organisations have tried to solve this type of SCM related strategic problems through inter-firm's dependence. That is why Resource Dependence Theory (RDT) is a related theory to underpin the research on its relationship between GSCM practices and performances. RDT can describe the surroundings of an organisation and its domain implying that individual firms can barely achieve sustainable growth. Therefore, organisations rely on a mutual relationship among the partners through SC collaboration. Sarkis et al. (2011) also highlighted that the success of implementing GSCM rely on the interdependency of partners in the SC as well as the collaborative approach and nature of their relationship. Based on RDT, firms that do not have necessary resources can build up relationship 
with other partners in the SC and obtain resources though SC collaboration. Tseng et al. (2009) supported this by saying that firms that are able to select from a wide variety of suppliers and leverage resources throughout the firm can eliminate the environmental impacts using the GSCM practices(Tseng et al., 2014). By doing so, all partners involved can not only reduce the negative impact on environment, but also enhance the business performance and build a stronger customersupplier relationship (Carter and Rogers, 2008; Cao and Zhang, 2010).

\subsection{Summary of the literature}

From the literature it is evident that integrating environmental practice in organisational activities has become an irreversible reality in order to sustainably survive and satisfy wider stakeholders. Greening the SCs is the innovation to achieve competitive advantage. GSCM practices requires time, capability, commitment and investment. However, firms usually initiate certain practices as long as business gains are involved. There are certain drivers and pressures in the literature broadly categorised as pro-active and reactive drivers by Laosirihongthong et al. (2013); coercive and noncoercive drivers by Tachizawa et al. (2015); internal and external drivers by Lee (2008); Testa and Iraldo (2010); Lee et al. (2012); Zailani et al. (2012) and so on. Firms get stimulations from the various sources of drivers and pressures to practice GSCM in their operations. Due to external pressures (regulations, competition and customer's expectation) and internal driving forces such as commitments from top management based on organisational values, support from mid-level managers and senior employees and expected business gains, companies are institutionalising the environmental practices in business operations. Hence, institutional theory was used. Many organisations are practicing GSCM as internal environmental management, green purchasing, ecodesigning, investment recovery and cooperation with customers (Zhu and Sarkis, 2007). There are inconclusive arguments in the literature about whether GSCM practices improve performances or not (Zhu and Sarkis, 2004; Rao and Holt, 2005; Green Jr et al., 2012; Laari et al., 2016) which have evidence from both positive and negative performance outcomes. There were dissimilar components in measuring firm performance in the previous studies. Tseng et al. (2015) claimed that GSCM practices and firm performance have been comprehensibly studied but firms are unlikely to perform well without depending on the resources of partners in their supply chains. For SMEs due to the scarcity of resources including technological know-hows, knowledge and expertise, human and financial resources (Lee et al., 2012; Huang et al., 2015), dependence on the partners in their supply chains become critical. In order to minimise risks and complexities in their supply chains, inter-firm dependence to improve firm performance become inevitable. That's why resource dependence theory was used in this study to understand performance implications. In this study, performance was measured considering operational efficiency, brand image and profitability. 


\section{Development of Hypotheses and the Conceptual Framework}

Based on the literature it is evident that organisations are often driven by stimuli which encourage or force firms to implement GSCM initiatives. Internal drivers are proactive and come from within the organisation and external pressures are reactive which arise from external stakeholders as highlighted in the Institutional Theory. The stimulus may come from inside the organisation or from external environment. So, two hypotheses are posited:

\section{$H_{1}$ : Internal drivers have positive impact on practicing GSCM}

\section{$\mathrm{H}_{2}$ : External pressures have positive impact on practicing GSCM}

The reviewed literature also demonstrates that there is a relationship between GSCM practices and organisational performance. In this analysis, overall organisational performance will be measured using operational efficiency, brand Image and profitability. Organisations are dependent on specific resource to each other in SC related activities between departments or between firms for improved performance. Literature shows that many organisations are solving SCM related strategic problems through inter-firm dependencies. GSCM practices enhance operational efficiency which can be indicated by working ability, lead time and service quality. Zhu and Sarkis (2004) mentioned Just in Time and Quality Management which latter extended to Total Quality Management and Total Quality Environmental Management practices as the indicators for operational efficiency. GSCM practices help firms utilise resources efficiently (Azevedo et al., 2011) reduce lead time and cost, enhance product quality and create better customer value (Green Jr et al., 2012; Lee et al., 2012). As GSCM practices help facilitate reduced lead time and improve quality reducing defects so the following hypothesis is proposed:

\section{$H_{3}$ : GSCM practices have a positive impact on operational efficiency}

GSCM advocates for environment friendly, socially responsible, ethically bound and fair policy practiced organisation. These practices send messages to the stakeholders about its activities and the organisation, and show that firms are doing well by doing good. Though Testa and Iraldo (2010) suggested that GSCM practices enhance brand image but Eltayeb et al. (2011) argued that intangible outcomes for instance company image has not been given proper attention as the outcome of GSCM practices. Later, Azevedo et al. (2011) appealed that nurturing environmental practices in firm's activities helps establish green image which will appeal environmentally aware stakeholders (i.e. customers, suppliers, employees and so on). So the following hypothesis is proposed:

\section{$\mathrm{H}_{4}$ : Perceived GSCM practices have a positive impact on brand image}

Through green practices in the operations, a firm can reduce waste by eliminating obsolescence cost, plummeting buffer stocks and reducing cost through practicing reverse logistics. In this way, a firm can reduce cost and enhance profitability. Practicing GSCM an organisation can create positive 
image in the society (Testa and Iraldo, 2010; Azevedo et al., 2011), customers are more satisfied and loyal through engaging various activities the organisation. So, GSCM practices help reduce cost and enhance profitability through increased sales and enhanced market share (Rao and Holt, 2005; Cao and Zhang, 2011). All this contributes to the financial gains of the firm. So, the following hypothesis is proposed:

\section{$H_{5}$ : GSCM practices have a positive impact on profitability}

With the above hypotheses, the following framework can be posited:

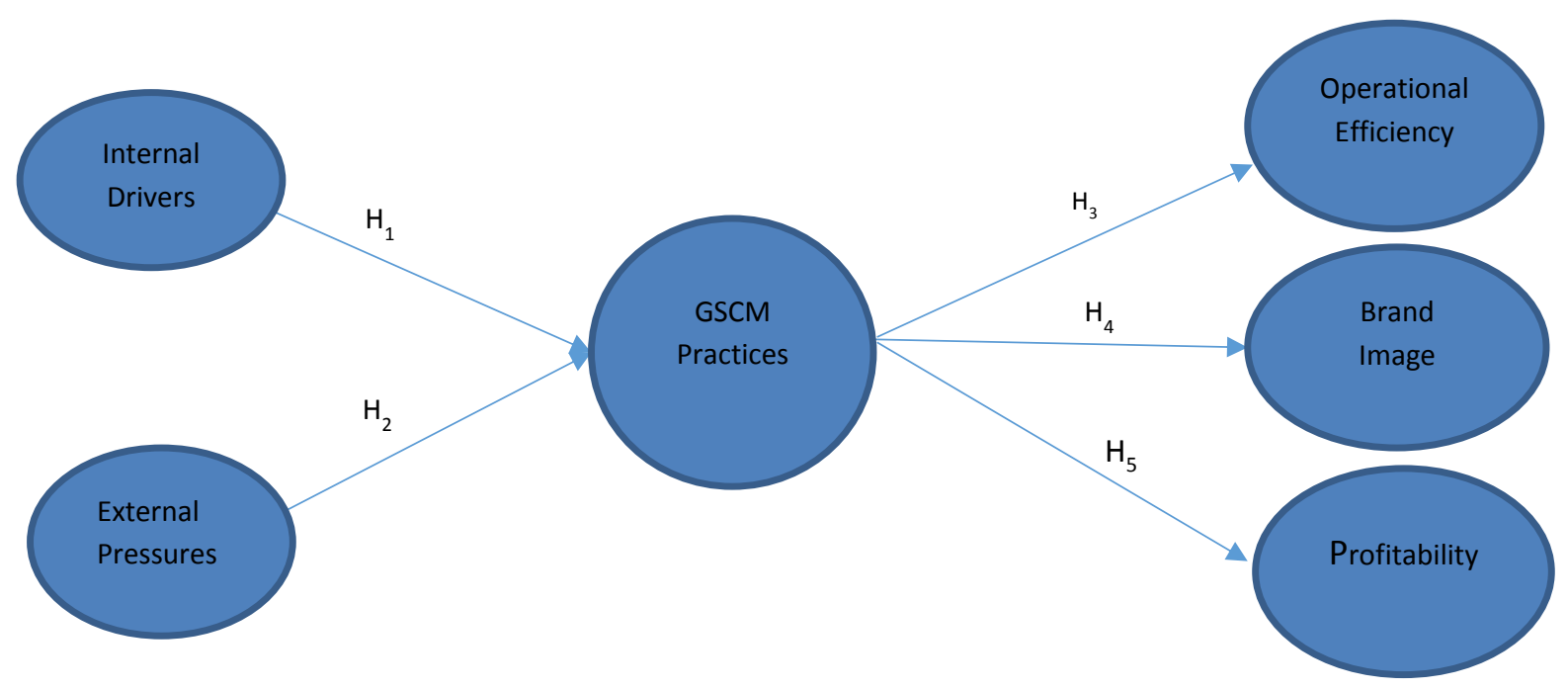

Figure 1: A framework of GSCM and the impact on the performance of UK food retail SMES

\section{Research Methodology}

\subsection{Operationalization of variables}

To operationalize the variables that will be used to test above hypotheses, a survey questionnaire based on the literature review for this study was developed. The Questionnaire includes 22 items in total - 3 items each on internal drivers and external pressures, 4 on GSCM, and 2 each on efficiency, brand image and profitability, and 6 on demography. Data were collected by visiting the food retail SME premises selected for this study. The respondents of this study were owners, managers or experienced employees responsible for supply chain related activities of the SMEs. In order to improve the validity of the research, as discussed in the sections above, a comprehensive review of previous literature on the topic of GSCM was conducted. Four senior researchers in the domain were consulted in person. The survey used Likert's 5-point scale to indicate the extent to which participants agree or disagree to a statement ranging from 1-5 (1= Strongly Disagree and $5=$ Strongly Agree). Measurement items for this study were developed and modified based on previous studies are shown below in the Table 2. 
Table 2 Measurement items

\begin{tabular}{|c|c|c|}
\hline Variables & Item ID* & Item content \\
\hline \multirow{3}{*}{$\begin{array}{l}\text { Internal } \\
\text { Drivers }\end{array}$} & ID1 & Commitment from top/senior management (Zhu and Sarkis, 2004) \\
\hline & ID2 & Support from managers and senior employees (Zhu and Sarkis, 2007) \\
\hline & ID3 & Expected Business Gains (Diabat and Govindan, 2011) \\
\hline \multirow[t]{3}{*}{$\begin{array}{l}\text { External } \\
\text { Pressures }\end{array}$} & EP1 & $\begin{array}{l}\text { Rules and Regulations (Zhu et al., 2007; Lee, 2008; Walker and Preuss, } \\
\text { 2008; Green Jr et al., 2012; Laosirihongthong et al., 2013) }\end{array}$ \\
\hline & EP2 & $\begin{array}{l}\text { Customer's Expectation (Walker and Preuss, 2008; Green Jr et al., } \\
\text { 2012) }\end{array}$ \\
\hline & EP3 & Market forces (Zhu et al., 2007; Walker and Preuss, 2008) \\
\hline \multirow{4}{*}{$\begin{array}{l}\text { GSCM } \\
\text { Practices }\end{array}$} & GSCM1 & Internal environmental management (Zhu and Sarkis, 2007) \\
\hline & GSCM2 & Green Purchasing (Zhu and Sarkis, 2007) \\
\hline & GSCM3 & Eco-Design(Zhu and Sarkis, 2007) \\
\hline & GSCM4 & Cooperation with customers(Zhu and Sarkis, 2007) \\
\hline \multirow{2}{*}{$\begin{array}{l}\text { Operational } \\
\text { Efficiency }\end{array}$} & OE1 & Reduced lead time (Lee et al., 2012) \\
\hline & OE2 & Improved quality (Lee et al., 2012; Jabbour et al., 2015) \\
\hline \multirow[t]{2}{*}{ Brand Image } & $\mathrm{BI1}$ & Customer's perceptions \\
\hline & $\mathrm{BI} 2$ & Customer's loyalty and trust \\
\hline \multirow[t]{2}{*}{ Profitability } & P1 & Reduction of Costs (Lee et al., 2012; Laosirihongthong et al., 2013) \\
\hline & P2 & $\begin{array}{l}\text { Financial gains through increased sales (Rao and Holt, 2005; Cao and } \\
\text { Zhang, 2011) }\end{array}$ \\
\hline
\end{tabular}

Keys: ID - Internal Drivers; EP - External Pressures; GSCM - Green Supply Chain Management; OE - Operational Efficiency; BI - Brand Image; P - Profit

\subsection{Population and Sample Size}

For this study, an initial plan was to collect data from SMEs that had been issued with ISO14001 certification. However, when the researcher visited some SME premises and spoken to the duty managers, it was found that not many SMEs had the ISO14001 certification. Thus, the samples for this study are the SMEs that practice some kind of green initiatives in terms of sourcing, producing and selling within London. One of the key criteria for selecting SMEs for this research was having commitments from the top managers who take environmental issues into consideration when sourcing products, recycling and reusing the products, and engaging customers in green practices. Another criterion was the size of the SMEs, i.e. with an employment between 10 and 250 people. To accomplish the objective of this study, a researcher administered questionnaire was devised and data were collected through visiting business premises with permission from the owners and senior managers responsible for sourcing and supply chain related decisions. A convenience sampling technique was employed to avoid difficulties in acquiring valid data. Questionnaires were 
administered in person in order to be able to answer possible questions about the questionnaire from the participants. In total 84 valid responses were collected from 115 SMEs approached, which represent a response rate of 73 percent. In order to detect a minimum $R^{2}$ value of 0.25 in any of the constructs for significant level of 1\%, the minimum sample size required is 84 (Hair et al., 2014). This requirement is met since 84 valid responses were collected.

\section{Data Analysis and Discussion of Findings}

Based on the empirical data, the hypotheses of the proposed conceptual model were tested in Structural Equation Modelling (SEM) deploying Partial Least Squares (PLS) with the help of Smart PLS 2.03 software (Ringle et al., 2005). SEM is a second generation multivariate statistical analysis that has drawn attention for testing hypotheses in the area of operations management (Peng and Lai, 2012). Smart PLS is recommended for smaller sample size (Chin, 1998) because the estimates of the individual path coefficients are more conservative than in covariance-based techniques (Hulland, 1999). In addition, the PLS is component based technique which is not restricted to multivariate normal data (Chin, 1998).

To ensure that the model was measured adequately, it was evaluated by considering the internal consistency (composite reliability), indictor reliability, and convergent validity (Hair et al., 2014). The composite reliability scores summarised in Table 3 indicated that these constructs should be consistent, since all constructs met the recommended threshold value for acceptable reliability, that is, composite reliability should be greater than 0.70 . With respect to Cronbach's $\alpha$, while some of the values were below the generally agreed 0.70 threshold, which is less than satisfactory and could be attributable to smaller sample size (Pallant, 2010); all values are above or close to 0.60 that is acceptable in exploratory research (Hair et al., 2010). Taken together, the model's internal consistency reliability was satisfactory. The indicator reliability (see Table 3) was first assessed by observing the factor loadings and each indicator's variance, the former should be large than 0.70 and the latter should be no less than 0.50 . All but one factor loadings were either above or close to 0.70; however, GSCM3's loading was 0.163 that was not satisfactory and thus was deleted. All variances were above 0.5 except that the variances of ED2 and ID1 were below 0.5. Therefore, indicator reliability is not entirely satisfactory but acceptable. Convergent validity was also satisfactory since the average variance extracted (AVE) value for each construct in Table 3 was no less than the recommended threshold value of 0.50 . 


\begin{tabular}{|c|c|c|c|c|c|c|}
\hline Construct & Indicators & Loading & $\begin{array}{l}\text { Indicator } \\
\text { Reliability }\end{array}$ & $\begin{array}{l}\text { Composite } \\
\text { reliability }\end{array}$ & Cronbach's $\alpha$ & $A V E$ \\
\hline \multirow{3}{*}{$\begin{array}{l}\text { Internal } \\
\text { Drivers }\end{array}$} & ID1 & 0.62 & 0.38 & \multirow[t]{3}{*}{0.78} & \multirow[t]{3}{*}{0.61} & \multirow[t]{3}{*}{0.55} \\
\hline & ID2 & 0.84 & 0.71 & & & \\
\hline & ID3 & 0.75 & 0.57 & & & \\
\hline \multirow{3}{*}{$\begin{array}{l}\text { External } \\
\text { Pressures }\end{array}$} & EP1 & 0.85 & 0.72 & \multirow[t]{3}{*}{0.80} & \multirow[t]{3}{*}{0.65} & \multirow[t]{3}{*}{0.57} \\
\hline & EP2 & 0.65 & 0.43 & & & \\
\hline & EP3 & 0.76 & 0.58 & & & \\
\hline \multirow{3}{*}{$\begin{array}{l}\text { GSCM } \\
\text { Practices }\end{array}$} & GSCM1 & 0.92 & 0.85 & \multirow[t]{3}{*}{0.89} & \multirow[t]{3}{*}{0.82} & \multirow[t]{3}{*}{0.74} \\
\hline & GSCM2 & 0.71 & 0.51 & & & \\
\hline & GSCM4 & 0.93 & 0.87 & & & \\
\hline \multirow{2}{*}{$\begin{array}{l}\text { Operational } \\
\text { Efficiency }\end{array}$} & OE1 & 0.92 & 0.85 & \multirow[t]{2}{*}{0.88} & \multirow[t]{2}{*}{0.79} & \multirow[t]{2}{*}{0.78} \\
\hline & OE2 & 0.84 & 0.72 & & & \\
\hline \multirow{2}{*}{$\begin{array}{l}\text { Brand } \\
\text { Image }\end{array}$} & $\mathrm{BI} 1$ & 0.88 & 0.77 & \multirow[t]{2}{*}{0.81} & \multirow[t]{2}{*}{0.54} & \multirow[t]{2}{*}{0.68} \\
\hline & $\mathrm{BI} 2$ & 0.77 & 0.59 & & & \\
\hline \multirow[t]{2}{*}{ Profitability } & P1 & 0.73 & 0.54 & \multirow[t]{2}{*}{0.81} & \multirow[t]{2}{*}{0.68} & \multirow[t]{2}{*}{0.68} \\
\hline & $\mathrm{P} 2$ & 0.90 & 0.82 & & & \\
\hline
\end{tabular}

The SEM results demonstrate that the proposed hypothesises were positively correlated and all but one was significant. A summary of the empirical results is shown in Figure 2.

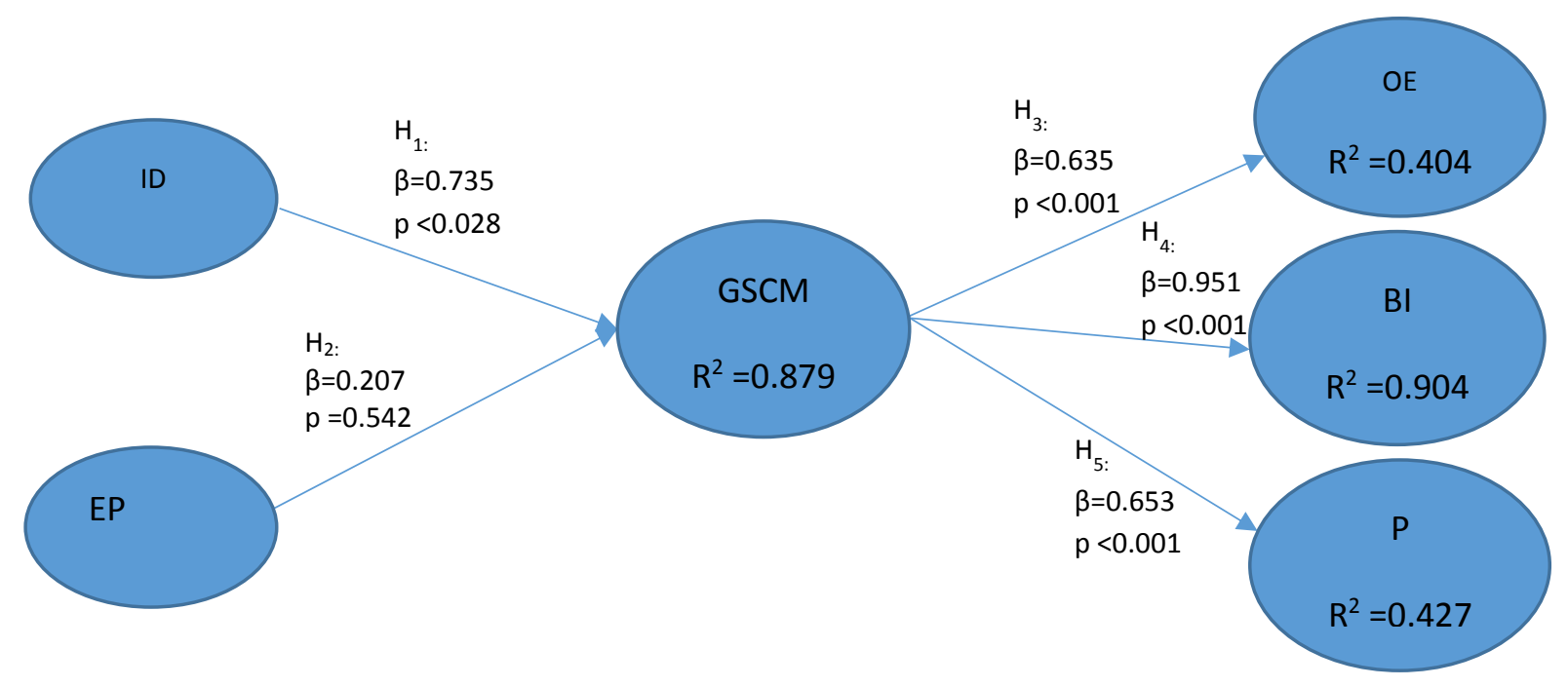

Figure 2. Summary of the empirical results

Figure 2 demonstrate the empirical results where the predictive power of the model was assessed by the amount of variance attributed to the latent variables (i.e., $R^{2}$ ). The $R^{2}$ values indicate that the full model explains $87.9 \%$ of the variance in GSCM, $40.4 \%$ in operational efficiency (OE), $90.4 \%$ in 
brand image (BI), 42.7\% in profitability (P). According to Hair et al. (2011) the effect size suggested for $R^{2}$ is weak $=0.25$, moderate $=0.50$, and substantial $=0.75$. In line with this, the effect sizes of GSCM and brand image can be classified as substantial; and the effect sizes of operational efficiency and profitability are between weak and moderate, but closer to moderate. In addition, Figure 2 implies that the Internal Drivers (ID) and External Pressures (EP) predict GSCM practices and simultaneously GSCM predicts Operational Efficiency (OE), Brand Image (BI) and Profitability (P). The empirical findings suggest that hypotheses $\left(\mathrm{H}_{1}, \mathrm{H}_{3}, \mathrm{H}_{4}\right.$ and $\left.\mathrm{H}_{5}\right)$ were proven and accepted. However, External Drivers $\left(\mathrm{H}_{2}\right)$ was positive but did not show significant relationship which was not expected but at the same time, GSCM has a very higher $\mathrm{R}^{2}$, suggesting internal Drivers (ID) explains $87.9 \%$ of the variances. Moreover, this also supports previous studies by Tachizawa et al. (2015) who classified coercive (regulations and environmental standards) and non-coercive (internal, mimetic and normative) drivers for two types of GSCM practices as monitoring based and collaboration based. Though their study revealed that non-coercive drivers has positive impact on both of the GSCM approaches (monitoring and collaboration) while coercive drivers suggested different implications as positive impact on monitoring based GSCM practices but negative impact on collaboration based GSCM practices. Zhu et al. (2005) found that for GSCM practices marketing pressure (external pressure) is not that strong. One possible explanation for an insignificant external pressure could be the firm size. As SMEs are small in size and possibly do not receive much regulatory pressures, are not in fierce competition with large competitors in the market, and customer expectation of SMEs for GSCM practices is not probably high. One important aspect to note in the results of this study is that the Internal Drivers (ID) are positive and significant which means that SMEs have internal motivation to conduct GSCM practices. Therefore, the framework developed from this study can be expressed as: the internal drivers can influence organisations' GSCM practices which help improve brand image, and enhance operational efficiency and profitability. All these three dimensions are the indicators of organisational performance.

The results of this study confirm that GSCM practices have a positive impact on the business performance in UK food retail SMEs. While this study focuses on GSCM in UK food retail SMEs, it supports the findings from studies by Lenny Koh et al. (2007) who studied SCM practices in Turkey's SMEs; Azevedo et al. (2011) who researched on SCM and SC performance in the Portuguese automotive industries and Lee et al. (2012) who investigated SCM Practices and impact on performance in the SMEs of electronic Industry in Korea. Simultaneously, the relationship between GSCM practices and brand reputation was also assessed and it was found that there is a significant positive relationship. The association between GSCM practices and profitability was also found significant which supports the findings of Rao and Holt (2005) in South East Asian context; Green et 
al. (2012) in manufacturing firms and Laosirihongthong et al. (2013) in manufacturing firms in Thailand. The findings of this study clearly indicate that internal drivers (firm's commitment from senior management in line with organisational values, support from employees and long term vision for expected business gains) proactively stimulate SMEs in practicing GSCM while external pressures (regulations, customer requirements and market competition) was not significant for this study. Moreover, this study examined the existing GSCM practices in UK food retail SMEs and highlighted the key GSCM practices in these SMEs - internal environmental management, green purchasing or procurement, environmentally friendly design, and cooperating with customers.

\section{Theoretical and Managerial Implications}

This study enriches the existing theories on SCM, GSCM practices and organisational performance. Moreover, deploying institutional theory to understand the drivers and pressures in practicing GSCM and resource dependence theory to understand performance implications should help enhance the theoretical applications. As to practical impact, this study should also facilitate SMEs in assessing the necessity for the firm to practice GSCM. It is imperative for managers to understand the motivating factors and performance outcome to initiate GSCM practices in firms' operations. If it can be perceived that there are long term gains for GSCM operations, managers are more likely to be more actively involved in such green practices. Moreover, as the UK government is campaigning for greener economy, it is only possible when SMEs, which consists $99 \%$ of UK businesses, are greening business operations, and working in collaboration with supply chain partners.

One of the key contributions of this study is the determination of internal drivers as a strong motivator for the GSCM practices in food retail SMEs. The internal drivers consist of the commitments from senior management (Zhu and Sarkis, 2004; Lee et al., 2013) driven by company values (Carter and Rogers, 2008), support from senior employees (Zhu et al.,2007) and expected business gains (Diabat and Govindan, 2011). External pressures are regulatory pressures (Azevedo et al., 2011; Laosirihongthong et al., 2013), consumer expectation (Walker and Preuss, 2008; Diabat and Govindan, 2011) and market forces (Walker et al., 2008). Organisations practice GSCM due to internal drivers but when firms are incapable of doing so, then motivation or pressures may come from the external environment (Bowen et al. (2001) which, however, did not seem to work for SMEs in this study as the empirical findings in this study could not prove significant relationships between external pressures and GSCM practices. This may be because of the size of SMEs, they are not having enormous pressures from governments, they are not probably in fierce competition with the competitors or the customer's pressures for environmental practices from SMEs is not high as well. This confirms the result from the study by (Huang et al., 2012) who pointed out that drivers and 
GSCM practices in SMEs significantly vary depending on the category and the contexts of the firm. In addition, Tachizawa et al. (2015) found different implication for internal and external drivers in environmental practices.

Another contribution, which is related to the second objective of this study, is the identification of the existing GSCM practices in the SMEs investigated which include internal environmental management, green purchasing and cooperation with customers. Finally, this study has proved that GSCM practices have a positive impact on organisational performance. Besides, this study has found that SMEs' brand image can be improved by implementing GSCM practices. Moreover, this research incorporates the key elements of the GSCM practice model developed by Zhu and Sarkis (2004); Zhu et al. (2007), the motivating factors of practicing GSCM by deploying institutional theory, and the performance implications by applying resource dependence theory. It can be concluded that, because of certain internal drivers UK food retail SMEs have started to implement GSCM practices such as internal environmental management, green purchasing and cooperating with customers. It is proposed that SMEs adopt GSCM practices to reduce the environmental impact on operations and improve efficiency, boost brand image and to increase their firms' overall profitability.

\section{Conclusions}

This section summarises the findings of this study, pointing out the limitations and the potential for future research in this area. The key findings of this study include: (a) internal drivers are strong motivators for SMEs to practice GSCM while external pressures are not significant; (b) GSCM practices such as internal environmental management, green purchasing and cooperation with customers are in practice in UK SMEs; (c) SMEs that practising GSCM can improve company reputation and result in higher loyalty and improved sales, and therefore augmented profit. As a result, GSCM practices can help SMEs enhance the overall business performance while maintaining product/service quality, saving energy, reducing costs and improving efficiency. This supports the outcomes of previous studies (Rao and Holt, 2005; Zhu et al., 2013)that GSCM practices have positive influence on efficiency and profitability. However, GSCM practices can be difficult for SMEs due to the size of their business, lack of expertise, financial constraints, and so on. Nevertheless, this study indicates that the SMEs that have implemented GSCM practices in one way or the other will enjoy the performance benefits in longer term.

Although this study makes important contributions to both theory and practice, there are a few limitations that open up avenues for further research. Firstly, the findings were based on the data collected only from UK food retail SMEs. Secondly, in comparison to the total number of UK food 
retail SMEs, the sample size for this study is relatively small. Thirdly, the research domain itself may limit the generalizability of the results because the findings in food retail SMEs may not be applicable to manufacturing or other types of SMEs. Finally, the use of single responses from participating SMEs may be seen as a limitation. However, to overcome this limitation, the data for this research were collected from the most informed people in the selected SMEs including senior managers, owners or senior employees.

Limitation of this study outlined above indicates potentials avenues for further research, for example, to examine how the size of a firm can affect its choice of GSCM practices; to conduct crosssector or sectorial comparison of GSCM practices in manufacturers with those in retail SMEs, and comparison of GSCM practices in large enterprises with those in SMEs; and to carry cross-country analysis may also provide valuable insights. Moreover, it is found in this study that external pressures for SMEs were not that significant. The possible reasons indicate further avenues to research. A larger sample size with multiple respondents form the same organisations should be worth studying. Nevertheless, this study contributes supporting the existing theories on GSCM and organisational performance. It also facilitates decision makers in assessing the necessity for practicing GSCM in SMEs highlighting the performance implications. While the findings of this study may have limited applicability as the data were collected from UK SMEs only, this research should help establish a foundation for further study in this domain.

\section{References:}

Ahi, P. \& Searcy, C. (2013). A comparative literature analysis of definitions for green and sustainable supply chain management. Journal of cleaner production, vol.52, pp.329-341.

Aragon-Correa, J. A., Hurtado-Torres, N., Sharma, S. \& Garcia-Morales, V. J. (2008). Environmental strategy and performance in small firms: A resource-based perspective. J Environ Manage, vol.86,no.1, pp.88-103.

Azevedo, S. G., Carvalho, H. \& Cruz Machado, V. (2011). The influence of green practices on supply chain performance: A case study approach. Transportation Research Part E: Logistics and Transportation Review, vol.47,no.6, pp.850-871.

Banaeian, N., Mobli, H., Nielsen, I. E. \& Omid, M. (2015). Criteria definition and approaches in green supplier selection-a case study for raw material and packaging of food industry. Production \& Manufacturing Research, vol.3,no.1, pp.149-168.

Beske, P., Land, A. \& Seuring, S. (2014). Sustainable supply chain management practices and dynamic capabilities in the food industry: A critical analysis of the literature. International Journal of Production Economics, vol.152, pp.131-143.

Bourlakis, M., Maglaras, G., Aktas, E., Gallear, D. \& Fotopoulos, C. (2014). Firm size and sustainable performance in food supply chains: Insights from greek smes. International Journal of Production Economics, vol.152, pp.112-130.

Bowen, F. E., Cousins, P. D., Lamming, R. C. \& Farukt, A. C. (2001). The role of supply management capabilities in green supply. Production and operations management, vol.10,no.2, pp.174189. 
Cao, M. \& Zhang, Q. (2010). Supply chain collaborative advantage: A firm's perspective. International Journal of Production Economics, vol.128,no.1, pp.358-367.

Cao, M. \& Zhang, Q. (2011). Supply chain collaboration: Impact on collaborative advantage and firm performance. Journal of Operations Management, vol.29,no.3, pp.163-180.

Carter, C. R. \& Rogers, D. S. (2008). A framework of sustainable supply chain management: Moving toward new theory. International journal of physical distribution \& logistics management, vol.38,no.5, pp.360-387.

Chen, S.-Y. \& Lee, T.-R. (Year) Published. Relationships between drivers, smes' adoption of green supply chain practices and performance. Supply Chain Management and Information Systems (SCMIS), 2010 8th International Conference on, 2010. IEEE, 1-6.

Chin, W. W. (1998). The partial least squares approach to structural equation modeling. Modern methods for business research, vol.295,no.2, pp.295-336.

De Giovanni, P. \& Esposito Vinzi, V. (2012). Covariance versus component-based estimations of performance in green supply chain management. International Journal of Production Economics, vol.135, no.2, pp.907-916.

Diabat, A. \& Govindan, K. (2011). An analysis of the drivers affecting the implementation of green supply chain management. Resources, Conservation and Recycling, vol.55,no.6, pp.659-667.

Dimaggio, P. J. \& Powell, W. W. (1983). The iron cage revisited-institutional isomorphism and collective rationality in organizational fields American Sociological Review, vol.48,no.2, pp.147-160.

Eltayeb, T. K., Zailani, S. \& Ramayah, T. (2011). Green supply chain initiatives among certified companies in malaysia and environmental sustainability: Investigating the outcomes. Resources, Conservation and Recycling, vol.55,no.5, pp.495-506.

Gold, S., Seuring, S. \& Beske, P. (2010). Sustainable supply chain management and interorganizational resources: A literature review. Corporate social responsibility and environmental management, pp.n/a-n/a.

Govindan, K., Kaliyan, M., Kannan, D. \& Haq, A. N. (2014). Barriers analysis for green supply chain management implementation in indian industries using analytic hierarchy process. International Journal of Production Economics, vol.147, pp.555-568.

Green Jr, K. W., Zelbst, P. J., Meacham, J. \& Bhadauria, V. S. (2012). Green supply chain management practices: Impact on performance. Supply Chain Management: An International Journal, vol.17,no.3, pp.290-305.

Grekova, K., Calantone, R., Bremmers, H., Trienekens, J. \& Omta, S. (2015). How environmental collaboration with suppliers and customers influences firm performance: Evidence from dutch food and beverage processors. Journal of cleaner production.

Gunasekaran, A., Subramanian, N. \& Rahman, S. (2015). Green supply chain collaboration and incentives: Current trends and future directions. Transportation Research Part E: Logistics and Transportation Review, vol.74, pp.1-10.

Hair, J. F., Black, W. C., Babin, B. J. \& Anderson, R. E. (2010). Multivariate data analysis, Prentice Hall Higher Education.

Hair, J. F., Ringle, C. M. \& Sarstedt, M. (2011). Pls-sem: Indeed a silver bullet. Journal of Marketing theory and Practice, vol.19, no.2, pp.139-152.

Hair, J. F., Hult, G., Ringle, C. \& Sarstedt, M. (2014). A primer on partial least squares structural equation modeling (pls-sem), Sage.

Hoejmose, S., Brammer, S. \& Millington, A. (2013). An empirical examination of the relationship between business strategy and socially responsible supply chain management. International Journal of Operations \& Production Management, vol.33,no.5, pp.589-621.

Holt, D. \& Ghobadian, A. (2009). An empirical study of green supply chain management practices amongst uk manufacturers. Journal of Manufacturing Technology Management, vol.20,no.7, pp.933-956. 
Hoskin, P. (2011). Why business needs to green the supply chain. University of Auckland Business Review, vol.13,no.1, pp.16.

Huang, X., Tan, B. L. \& Ding, X. (2012). Green supply chain management practices: An investigation of manufacturing smes in china. International Journal of Technology Management \& Sustainable Development, vol.11,no.2, pp.139-153.

Huang, X., Tan, B. L., Ding, X. \& Bennett, D. (2015). An exploratory survey of green supply chain management in chinese manufacturing small and medium-sized enterprises: Pressures and drivers. Journal of Manufacturing Technology Management, vol.26,no.1.

Hulland, J. (1999). Use of partial least squares (pls) in strategic management research: A review of four recent studies. Strategic management journal, vol.20,no.2, pp.195-204.

Jabbour, A. B. L. D. S., Jabbour, C. J. C., Latan, H., Teixeira, A. A. \& De Oliveira, J. H. C. (2015). Quality management, environmental management maturity, green supply chain practices and green performance of brazilian companies with iso 14001 certification: Direct and indirect effects. Transportation Research Part E: Logistics and Transportation Review, vol.67, pp.39-51.

Kuei, C.-H., Madu, C. N., Chow, W. S. \& Chen, Y. (2015). Determinants and associated performance improvement of green supply chain management in china. Journal of cleaner production, vol.95, pp.163-173.

Laari, S., Töyli, J., Solakivi, T. \& Ojala, L. (2016). Firm performance and customer-driven green supply chain management. Journal of cleaner production, vol.112, pp.1960-1970.

Laosirihongthong, T., Adebanjo, D. \& Choon Tan, K. (2013). Green supply chain management practices and performance. Industrial Management \& Data Systems, vol.113,no.8, pp.10881109.

Lee, S.-Y. (2015). The effects of green supply chain management on the supplier's performance through social capital accumulation. Supply Chain Management: An International Journal, vol.20,no.1, pp.42-55.

Lee, S. M., Tae Kim, S. \& Choi, D. (2012). Green supply chain management and organizational performance. Industrial Management \& Data Systems, vol.112,no.8, pp.1148-1180.

Lee, S. M., Sung Rha, J., Choi, D. \& Noh, Y. (2013). Pressures affecting green supply chain performance. Management Decision, vol.51,no.8, pp.1753-1768.

Lee, S. Y. (2008). Drivers for the participation of small and medium-sized suppliers in green supply chain initiatives. Supply Chain Management: An International Journal, vol.13,no.3, pp.185198.

Lenny Koh, S., Demirbag, M., Bayraktar, E., Tatoglu, E. \& Zaim, S. (2007). The impact of supply chain management practices on performance of smes. Industrial Management \& Data Systems, vol.107,no.1, pp.103-124.

Linton, J., Klassen, R. \& Jayaraman, V. (2007). Sustainable supply chains: An introduction. Journal of Operations Management, vol.25, no.6, pp.1075-1082.

Pallant, J. (2010). Spss survival manual 4th edition-a step by step guide to data analysis using the spss program. Österrike: Allen \& Unwin Book Publisher.

Peng, D. X. \& Lai, F. (2012). Using partial least squares in operations management research: A practical guideline and summary of past research. Journal of Operations Management, vol.30,no.6, pp.467-480.

Quayle, M. (2003). A study of supply chain management practice in uk industrial smes. Supply Chain Management: An International Journal, vol.8,no.1, pp.79-86.

Ramanathan, U., Bentley, Y. \& Pang, G. (2014). The role of collaboration in the uk green supply chains: An exploratory study of the perspectives of suppliers, logistics and retailers. Journal of cleaner production, vol.70, pp.231-241.

Rao, P. \& Holt, D. (2005). Do green supply chains lead to competitiveness and economic performance? International Journal of Operations \& Production Management, vol.25,no.9, pp.898-916.

Ringle, C., Wende, S. \& Will, A. (2005). Smart-pls version 2.0 m3. University of Hamburg. 
Saad, S., Perera, T., Achanga, P., Shehab, E., Roy, R. \& Nelder, G. (2006). Critical success factors for lean implementation within smes. Journal of Manufacturing Technology Management, vol.17,no.4, pp.460-471.

Sarkis, J., Zhu, Q. \& Lai, K.-H. (2011). An organizational theoretic review of green supply chain management literature. International Journal of Production Economics, vol.130,no.1, pp.115.

Sarkis, J. (2012). A boundaries and flows perspective of green supply chain management. Supply Chain Management: An International Journal, vol.17,no.2, pp.202-216.

Seuring, S. \& Müller, M. (2008). From a literature review to a conceptual framework for sustainable supply chain management. Journal of cleaner production, vol.16,no.15, pp.1699-1710.

Slack, N., Chambers, S. \& Johnston, R. (2009). Operations management, Pearson Education.

Subramanian, N. \& Gunasekaran, A. (2015). Cleaner supply-chain management practices for twentyfirst-century organizational competitiveness: Practice-performance framework and research propositions. International Journal of Production Economics, vol.164, pp.216-233.

Tachizawa, E. M., Gimenez, C. \& Sierra, V. (2015). Green supply chain management approaches: Drivers and performance implications. International Journal of Operations \& Production Management, vol.35,no.11, pp.1546-1566.

Testa, F. \& Iraldo, F. (2010). Shadows and lights of gscm (green supply chain management): Determinants and effects of these practices based on a multi-national study. Journal of cleaner production, vol.18,no.10-11, pp.953-962.

Thakkar, J., Kanda, A. \& Deshmukh, S. G. (2009). Supply chain management for smes: A research introduction. Management Research News, vol.32,no.10, pp.970-993.

Touboulic, A. \& Walker, H. L. (2015). A relational, transformative and engaged approach to sustainable supply chain management: The potential of action research. Human Relations.

Tseng, M.-L., Divinagracia, L. \& Divinagracia, R. (2009). Evaluating firm's sustainable production indicators in uncertainty. Computers \& Industrial Engineering, vol.57,no.4, pp.1393-1403.

Tseng, M.-L. \& Chiu, A. S. F. (2013). Evaluating firm's green supply chain management in linguistic preferences. Journal of cleaner production, vol.40, pp.22-31.

Tseng, M.-L., Lin, Y.-H., Tan, K., Chen, R.-H. \& Chen, Y.-H. (2014). Using todim to evaluate green supply chain practices under uncertainty. Applied Mathematical Modelling, vol.38,no.11, pp.2983-2995.

Tseng, M.-L., Tan, K. \& Chiu, A. S. (2015). Identifying the competitive determinants of firms' green supply chain capabilities under uncertainty. Clean Technologies and Environmental Policy, pp.1-16.

Vaaland, T. I. \& Heide, M. (2007). Can the sme survive the supply chain challenges? Supply Chain Management: An International Journal, vol.12,no.1, pp.20-31.

Vachon, S. \& Klassen, R. D. (2006). Extending green practices across the supply chain: The impact of upstream and downstream integration. International Journal of Operations \& Production Management, vol.26,no.7, pp.795-821.

Vachon, S. \& Klassen, R. D. (2008). Environmental management and manufacturing performance: The role of collaboration in the supply chain. International Journal of Production Economics, vol.111,no.2, pp.299-315.

Walker, H., Di Sisto, L. \& Mcbain, D. (2008). Drivers and barriers to environmental supply chain management practices: Lessons from the public and private sectors. Journal of Purchasing and Supply Management, vol.14,no.1, pp.69-85.

Walker, H. \& Preuss, L. (2008). Fostering sustainability through sourcing from small businesses: Public sector perspectives. Journal of cleaner production, vol.16,no.15, pp.1600-1609.

Ward, M. \& Rhodes, C. (2014). Small businesses and the uk economy. Standard Note: SN/EP/6078, House of Commons Library, vol.13. 
Wittstruck, D. \& Teuteberg, F. (2012). Understanding the success factors of sustainable supply chain management: Empirical evidence from the electrics and electronics industry. Corporate social responsibility and environmental management, vol.19,no.3, pp.141-158.

Wu, K.-J., Liao, C.-J., Tseng, M.-L. \& Chiu, A. S. F. (2015). Exploring decisive factors in green supply chain practices under uncertainty. International Journal of Production Economics, vol.159, pp.147-157.

Zailani, S., Jeyaraman, K., Vengadasan, G. \& Premkumar, R. (2012). Sustainable supply chain management (sscm) in malaysia: A survey. International Journal of Production Economics, vol.140,no.1, pp.330-340.

Zhu, Q. \& Sarkis, J. (2004). Relationships between operational practices and performance among early adopters of green supply chain management practices in chinese manufacturing enterprises. Journal of Operations Management, vol.22,no.3, pp.265-289.

Zhu, Q., Sarkis, J. \& Geng, Y. (2005). Green supply chain management in china: Pressures, practices and performance. International Journal of Operations \& Production Management, vol.25, no.5, pp.449-468.

Zhu, Q. \& Sarkis, J. (2007). The moderating effects of institutional pressures on emergent green supply chain practices and performance. International Journal of Production Research, vol.45, no.18-19, pp.4333-4355.

Zhu, Q., Sarkis, J. \& Lai, K. H. (2007). Initiatives and outcomes of green supply chain management implementation by chinese manufacturers. J Environ Manage, vol.85,no.1, pp.179-89.

Zhu, Q., Sarkis, J. \& Lai, K.-H. (2012). Examining the effects of green supply chain management practices and their mediations on performance improvements. International Journal of Production Research, vol.50,no.5, pp.1377-1394.

Zhu, Q., Sarkis, J. \& Lai, K.-H. (2013). Institutional-based antecedents and performance outcomes of internal and external green supply chain management practices. Journal of Purchasing and Supply Management, vol.19,no.2, pp.106-117. 